the challenge of taking a comprehensively national view tends to impose awkward generalizations, or skip over important constituents. On the point of constituents, this book ends with important insights into the recent work of the Alberta Métis Education Council to envision self-determination in education (chapter 11). Perhaps the publisher preferred to market this book as one that encompasses Indigenous education across Canada, or Carr-Stewart simply drew upon her networks in the places she has lived and worked, and explicit discussion about the west as an analytical frame did not emerge. Regardless, I would invite more discussion about whether taking a regional approach to Indigenous educational history and research makes a difference to researchers, reading audiences, and to the teachers, students, and community members whom schools serve.

Heather E. McGregor

Queen's University

Jody Mason

Home Feelings: Liberal Citizenship and the Canadian Reading Camp Movement

Montreal: McGill-Queen's University Press, 2019. 368 pp.

Jody Mason's interdisciplinary study of the reading camp movement through the early years of Frontier College and its indefatigable first principal, Alfred Fitzpatrick, offers a complex analysis of the entangled liberal projects of literacy and citizenship education and the importance of non-state actors in influencing government and public discourse and policy. Mason adopts a largely chronological approach, following the early years of the Canadian Reading Camp Association (CRCA) at the turn of the twentieth century through to its evolution into Frontier College and its work in the interwar and early postwar years. Through this chronology, Mason explores several important facets of the literary and citizenship education cultures in the camps served by the CRCA's reading rooms, travelling libraries, and labourer-instructors. Her central argument highlights the dynamic role of literacy - the culture of print and reading in the camps and the college leadership's emphasis on certain types of reading - in the context of the ongoing liberal prioritization of "home feelings," or "affective conceptions of citizenship" rather than collective-oriented ideals (11).

This emphasis on home feelings in the selection of literature for travelling libraries and reading rooms in work camps reflected a broader maternal, feminist approach to literacy and literature in an attempt to combat rough behaviour, radicalism, and jumping camp. In the early years of the CRCA, popular literature and poetry from authors like Ralph Connors sought to harness narratives of masculine individual development with affective calls to responsibility and domestic calm to "restore damaged familial bonds through books" (65). The influx of non-English speaking immigrants at the turn of the twentieth century forced a shift in this discourse, moving from an argument of providing reminders of home to a more overt 
project of Canadianization, where English reading skills were seen as key to successful integration. In the years leading up to the Depression, the newly chartered Frontier College shifted to a more active pedagogy centred on the labourer-instructor working to build language competency and a "common Canadian sentiment" amongst immigrants (168).

A second important thread that Mason weaves throughout her study is the dynamic between state and non-state actors. While Fitzpatrick abandoned his vision for degree-granting status for the college in part because of Ontario's threat to withhold provincial grants to the college in 1929, he and other Frontier College leaders persisted in a longer mission to secure government funding, shifting the rationale for the college's utility to the state and society over the course of its existence. While Fitzpatrick boasted early in the CRCA's existence of the association's work in providing home feelings for predominant English-speaking workers, by the interwar period this emphasis had shifted "from moral to political citizenship, from home to state, and from British- and native-born Canadians to non-British immigrants" (126). The liberal political citizenship espoused by Frontier College (and supported by the state in the peak years of the Depression) faced its stiffest test in the rise of socialist and labour organizing in government relief camps. In a compelling comparison of the Relief Camp Worker (a bulletin issue by the Relief Camp Workers Union) and the counter-literature offered by Frontier College, Mason skillfully teases out the nuanced differences in citizenship ideals of two very different literatures. The Relief Camp Worker presented citizenship as "a collective practice defined by social needs that the state has an obligation to meet" (188), while Frontier College's literature emphasized a citizenship grounded in individual "duties to the state and by the civil and political rights that shape these duties" (188). Returning to the home feelings of the early reading camp movement, literature promoted by Frontier College during these contested years focused on the sentimentality of individual togetherness (via singing and reading groups, for instance) rather than the class solidarity and collective action promoted by the Relief Camp Workers Union's literature (206-209).

Mason's use of a variety of archival sources in the Frontier College archives, combined with her sophisticated reading of a range of published sources from the era, gives her study depth and nuances discussions of other themes such as gender and class, particularly in discussions of the relationships between labourer-instructors and students. One area where her work can be pushed further by scholars of education and scholars of young people is in her occasional intersections with the theme of age and becoming. Whether it be her observations about the popularity of adventure writers like Ralph Connors for both the men in camp and the CRCA's own choice of preferred literatures, Frontier College's challenges in finding age-appropriate instructional texts for teaching adult English as additional language learners, or the postwar popularity of American comics with men as something Frontier College worked to counter by turning to more appropriate literary pursuits like Shakespeare, the intersection between citizenship training for young people (particularly boys, in this instance) and the men targeted by Frontier College remains an area for potential development. Immigrant men, like boys across the country, were targeted throughout 
the twentieth century for citizen-building projects and, while not a central part of Mason's work, assessing how these efforts differed or converged through the lens of age and concern about citizens-in-the-making could be most fruitful.

Home Feelings is an excellent interdisciplinary study that fills an important niche in the history of education and literary cultures in Canada. Mason smartly positions the book in the context of debates around citizenship education most recently embodied in the tensions and controversies around the 2009 Discover Canada citizenship guide released by the Conservative government of Stephen Harper. Through the compromises within citizenship discourse and the persistence of the vision of the individual as one "who exists within an intimate rather than a collective construction of social relations" (234), Mason provides excellent points of engagement. This book would make excellent reading for graduate or senior undergraduate students in a range of disciplines interested in education, literacy, literature, labour, and gender history.

James Trepanier Canadian Museum of History

Paul W. Bennett

\section{The State of the System: A Reality Check on Canada's Schools}

Montreal: McGill-Queen's University Press, 2020. 256 pp.

Paul Bennett's 2020 "reality check on Canada's schools" will strike the right notes with some readers disposed toward school reform. In The State of the System, Bennett argues that public schools "have lost their way and have become largely unresponsive to the public they still claim to serve" (3). Bennett's is a "plan to reclaim them for students, parents, teachers, and communities alike" (3). Well-written and referenced, this check on Canada's schools is a sophisticated appeal to populism that will resonate with those who believe that education is an urbanized, bureaucratic, centralized system that has triumphed over students, parents, teachers, and the engaged public.

The State of the System follows a path that Bennett has traveled before. ${ }^{1}$ That he is familiar with both popular and scholarly literature and is an able writer will be no surprise to those who have read his prior work or his blog. ${ }^{2}$ Bennett has employed the theme of a Manichean, David and Goliath struggle between state schooling and local, community-based education at least as far back as his 1990 doctoral thesis. ${ }^{3}$ For Bennett, reformation of public schooling is principally about wresting

1 Paul W. Bennett, "Consolidation, Bureaucracy and the Public Schools: The Formation of the Modern Bureaucratic State, 1920 to 1993," Canadian Issues (2014):16-22; Paul W. Bennett, Vanishing Schools, Threatened Communities: The Contested Schoolhouse in Maritime Canada, 1850-2010 (Halifax and Winnipeg: Fernwood Publishing, 2011).

2 https://educhatter.wordpress.com/

3 Paul W. Bennett, “'Little Worlds': The Forging of Social Identities in Ontario's Protestant School Communities and Institutions, 1850-1930," (Phd diss., University of Toronto, 1990). 